\title{
Geochemistry of arsenic and selenium in a Ge-poor coal from the Wulantuga coal-hosted Ge ore deposit, Inner Mongolia, North China
}

\author{
Panpan Xie $\cdot$ Qingqian Li $\cdot$ Jingjing Liu $\cdot$ Hongjian Song $\cdot$ Jianpeng Wei
}

Received: 24 November 2014/Revised: 12 December 2014/Accepted: 15 December 2014/Published online: 10 March 2015

(C) The Author(s) 2015. This article is published with open access at Springerlink.com

\begin{abstract}
This paper reports new data for arsenic (As) and selenium (Se) in a total of twelve bench samples of Ge-rich and Ge-poor coals in the No. 6 coal seam from the Wulantuga ore deposit, Inner Mongolia, Northeastern China. The Gepoor coals are characterized by low-ash (with a weighted average ash yield $10.59 \%$ ). The coal samples were digested using an UltraClave microwave high pressure reactor (milestone) and trace elements were detected by inductively coupled plasma mass spectrometry-collision/reaction cell technology, a reliable method for As and Se determination in coal samples. The contents of As and Se in the Ge-poor (with a weighted average content of 9.14 and $0.30 \mu \mathrm{g} / \mathrm{g}$, respectively) and Ge-rich coal samples in the present study (varies from 16.88 to $17,776 \mu \mathrm{g} / \mathrm{g}$ and from 0.26 to $14.39 \mu \mathrm{g} / \mathrm{g}$, respectively) are in a sharp contrast. The As in the Ge-poor coals is of both organic- and pyrite-associations, and its enrichment is attributed to the sediment source, and to a lesser extent, to hydrothermal fluids. Se is predominantly connected with organic matter in the Wulantuga Ge-poor coals.
\end{abstract}

Keywords Arsenic $\cdot$ Selenium $\cdot$ Wulantuga Ge ore deposit

\section{Introduction}

The interests and concerns on studying arsenic and selenium have been and are increasing worldwide (Vladimir and Karel 1977; Vladimir et al. 1977; Ren et al. 1999; Dai et al. 2003; Tang and Huang 2004; Shao et al. 2006), due to their high toxicity and hence the adverse effects on human health and environments. Particularly, the serious arsenic poisoning caused by in-door coal burning in the west of Guizhou Province (Dai et al. 2003, 2005) has attracted much attention. Being different from the Ge-rich coals in the Wulantuga ore deposit, the content of germanium in the present study is rather low. This paper reports the contents, modes of occurrence, and genetic origins of arsenic and selenium in the No. 6 coal seam from the Wulantuga ore

P. Xie $(\bowtie) \cdot$ Q. Li $\cdot$ J. Liu $\cdot$ H. Song $\cdot$ J. Wei College of Geoscience and Surveying Engineering, China University of Mining and Technology (Beijing), Beijing 100083, China

e-mail: 18813150041@163.com deposit, Inner Mongolia, North China, which, however, have never been reported previously. Additionally, the digestion method with an UltraClave microwave high pressure reactor (milestone) and the analytical procedures for arsenic and selenium contents by ICP-CCT-MS were also discussed in detail.

\section{Geological background}

The Wulantuga Coal Mine is located at the southwest of Shengli coalfield, with a total area around $342 \mathrm{~km}^{2}, 45-\mathrm{km}$ long and 7.6-km wide. Belonging to a trapped and wide syncline and in the elevation scope of 970-1,212 m, the Shengli coalfield with smooth layers is located in the Wunite depression in the west of Erlian Basin in northeastern Inner Mongolia (Huang et al. 2007), covering the area between latitudes $43^{\circ} 54^{\prime} 15^{\prime \prime}$ and $44^{\circ} 13^{\prime} 52^{\prime \prime} \mathrm{N}$ and longitudes $115^{\circ} 24^{\prime} 26^{\prime \prime}$ and $116^{\circ} 26^{\prime} 30^{\prime \prime} \mathrm{E}$. The distance between the Early Cretaceous Wulantuga high-Ge and the studied Ge-poor coals ore deposit is around $300 \mathrm{~m}$. 
As illustrated in Fig. 1, the sedimentary strata in the Shengli coalfield contain Silurian, Devonian, Permian, Jurassic, Cretaceous, Neogene, and Quaternary sedimentary sequences (Dai et al. 2012a). The average thickness of the Silurian and Devonian sedimentary sequences is more than 2,363 m, including sericite-quartz schist, two-mica quartz schist, biotite-quartz schist, and quartzite. The thickness of the Permian strata varies from 680 to $3,550 \mathrm{~m}$. From top to bottom, the upper strata are predominantly made up of conglomerate, sandy mudstone, limestone, and lenses of andesitic tuff. The siltstone was interlayered in the limestone horizons. Bioclastic rocks, limestone, marl, sandstone, and andesite make up the lower part. The Jurassic strata have a thickness $>3,734 \mathrm{~m}$ and its compositions are characterized by mafic (such as basalts), intermediate-felsic (e.g., quartz trachyandesite and trachyandesite) and acid volcanic rocks (e.g., rhyolite). The Bayanhua Group contains three
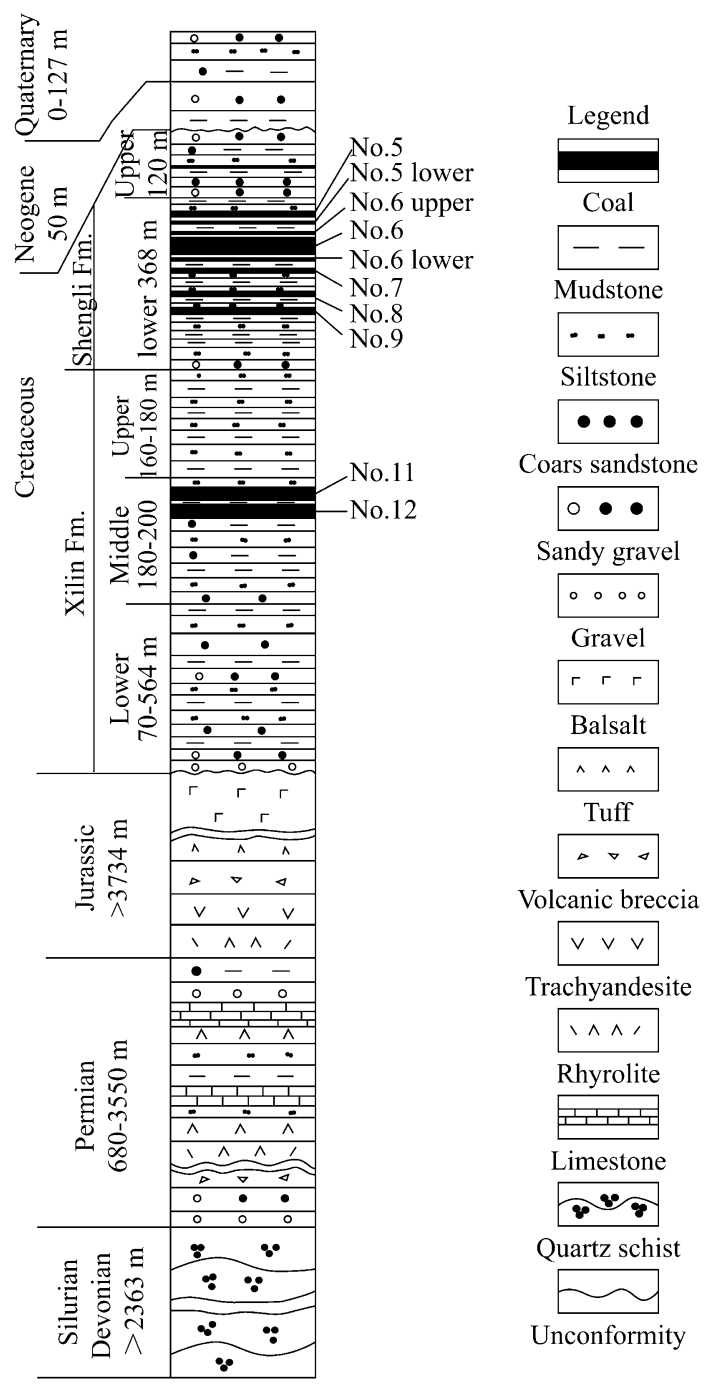

Fig. 1 Sedimentary sequence of the Wulantuga ore deposit (Dai et al. 2012a) formations, including the Aershan, Saihantala, and Hadatu Formations, which, however are absent in the study area (Sha 2007). The Aershan and Saihantala Formations are titled Xilin and Shengli Formations in this paper, respectively. The Nos. 11 (with an average thickness of $1.54 \mathrm{~m}$ ) and 12 ( $2.3 \mathrm{~m}$ on average) coal beds occur in the upper part of the Xilin Formation. The lower portion of the Shengli Formation (368 $\mathrm{m}$ on average), the major coal-containing strata, primarily consists of coal beds, fine sandstone, siltstone, coarse sandstone, mudstone, and conglomerate. Eight coal beds are included in the Shengli Formation: Nos. 5, 5-lower, 6-upper, 6, 6-lower, 7, 8, and 9, and average thicknesses are 14.96, 2.98, unmineable, $16.1,1.40,4.57,1.47$ and $1.33 \mathrm{~m}$, respectively. Furthermore, the currently-studied No. 6 coal seam (ranging from 0.8 to $36.2 \mathrm{~m}$ ) is the major coal bed in the Wulantuga Ge ore deposit (Dai et al. 2012a).

\section{Samples and analytical procedures}

Twelve bench coal samples were collected from the mined face of the No. 6 coal seam at the Wulantuga Mine in the Shengli coalfield in Inner Mongolia, including six coal ply and one roof samples from the Ge-poor coal seam; two fusains, one fly ash, one slag and one pyrite samples from the Wulantuga Ge-rich ore deposit. Following the Chinese Standard Method GB/T 482-2008 (2008), each coal ply sample was cut over a volume of $10-\mathrm{cm}$ deep and $10-\mathrm{cm}$ wide and was put into a clean and uncontaminated plastic bag to prevent pollution and oxidation. From top to bottom, the six coal samples were identified as WLTG-1 to WLTG-6, and the thickness of each sample in No. 6 coal seam is $50 \mathrm{~cm}$, except for the sample WLTG-3 $(66 \mathrm{~cm})$. The roof sample was numbered as WLTG-0-R. The two fusain samples were identified as WLTG-7-FU1 and WLTG-8-FU2, respectively. The fly ash sample was collected from baghouse filters and was numbered as WLTG-9-FA. The slag derived from Ge-rich coal and pyrite samples was identified as WLTG-10SL and WLTG-11-PY, respectively.

Prior to geochemical analysis, the samples were crushed and ground to pass the $75-\mu \mathrm{m}$ sieve using SM-1 type vibration grinding instrument. The samples weighed 50-mg were put into closed thermally fused melamine (TFM) digestion vessels whose span is $10 \mathrm{~mL}$. The further purified guaranteed-reagent (GR) $\mathrm{HNO}_{3}$ using a sub-boiling DuoPUR acid purification system (Milestone) and the metaloxide-semiconductors reagent $\mathrm{HF}$ were used for sample digestion ( $\mathrm{Li}$ et al. 2014). Taking into consideration the strong dispelling capacity of $\mathrm{HF}$, the reagents include 5-mL $40 \%(V / V) \mathrm{HF}$ and 2-mL $65 \%(V / V) \mathrm{HNO}_{3}$ for each noncoal sample materials, but for coal samples, the reagents were composed of 2-mL $40 \% \mathrm{HF}$ and 5-mL $65 \% \mathrm{HNO}_{3}$. An UltraClave microwave high pressure reactor 
(milestone) was applied to digest samples prior to ICPCCT-MS analysis. The basic load for the TFM tank of UltraClave reactor is composed of 2-mL $98 \% \mathrm{H}_{2} \mathrm{SO}_{4}$ (GR reagent), 30-mL $30 \% \mathrm{H}_{2} \mathrm{O}_{2}$ (MOS reagent), 330-mL Mili$\mathrm{Q} \mathrm{H}_{2} \mathrm{O}$ (Dai et al. 2011). The microwave digestion program contains five steps with the temperature rising from 60 to $240{ }^{\circ} \mathrm{C}$, the pressure increasing from 100 bars to 160 bars, and $60 \mathrm{~min}$ are needed for cooling and decompression. The contents of arsenic and selenium in the samples were detected by inductively coupled plasma mass spectrometry (X seriesII, ICP/MS) plus collision cell technology (CCT), which could diminish the interferences of polyatomic ions (Li et al. 2014), and Ultra-pure and adequately mixed He $(93.33 \%)$ and $\mathrm{H}_{2}(6.67 \%)$ were used to be carriers of collision gases. NIST (National Institute of Standards and Technology) standard reference materials (e.g., NIST $2685 \mathrm{~b}$ ) were used for the calibration of arsenic and selenium contents obtained by ICP-CCT-MS. In order to avoid residues that can affect the precise content of trace elements, ultra-pure $\mathrm{H}_{2} \mathrm{O}$ and $2 \%(V / V) \mathrm{HNO}_{3}(65 \%)$ are used to flush pipeline in turn, for 5 and $10 \mathrm{~min}$, respectively. The $1 \mu \mathrm{g} / \mathrm{L}$ tuning solution containing lithium, cobalt, indium and uranium and $10 \mu \mathrm{g} / \mathrm{L}$ internal standard solution containing single element rhodium are used to regulate the best state of ICP/MS before test beginning. A series of different content solutions diluted from standard solution $100 \mu \mathrm{g} / \mathrm{mL}$ (Inorganic Ventures, CCS4) were used to determine calibration curves of arsenic and selenium. All standard solutions mentioned above use $2 \%(\mathrm{~V} / \mathrm{V})$ $\mathrm{HNO}_{3}(65 \%)$ as the substrate.

As listed in Fig. 2, Tables 1 and 2, the linearity of the calibration curves in the range $0-100 \mu \mathrm{g} / \mathrm{L}$ is considered as a satisfying parameter with a correlation coefficient $r^{2}>0.9999$. The $\%$ errors within $10 \%$ of standard solutions showed in Table 1 are also assurances of the reliable contents of arsenic and selenium. The digestion method and the ICP/MS analysis technology for Ge determination in the samples were outlined by Dai et al. (2011).

\section{Results and discussion}

Under the guidance of optimized experimental conditions above, both the observed contents and the certified values of arsenic and selenium in NIST 2685b determined by ICP-CCT-MS are listed in Table 3.

As presented in Table 3, the relative errors of arsenic $(6.33 \%)$ and selenium $(0.53 \%)$ between the observed and certified values are within $10 \%$, suggesting the high reliability for both the digestion method by UltraClave microwave high pressure reactor and the ICP-CCT-MS technology for the determination of arsenic and selenium in the samples.

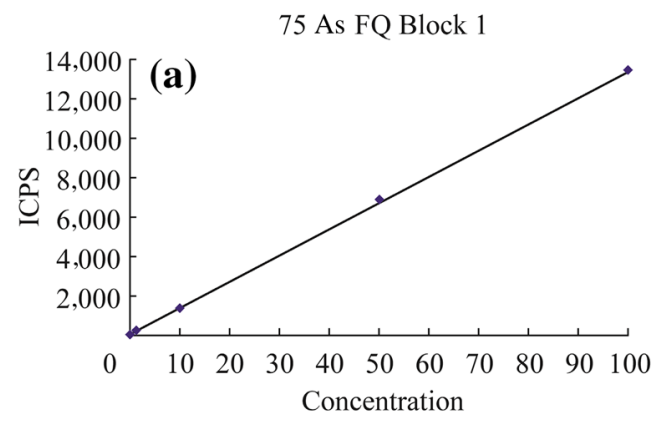

Intercept CPS $=110.752257$ Intercept $\mathrm{Conc}=0.828535$

Sensitivity $=133.672326$ Correlation Coeff $=0.999947$

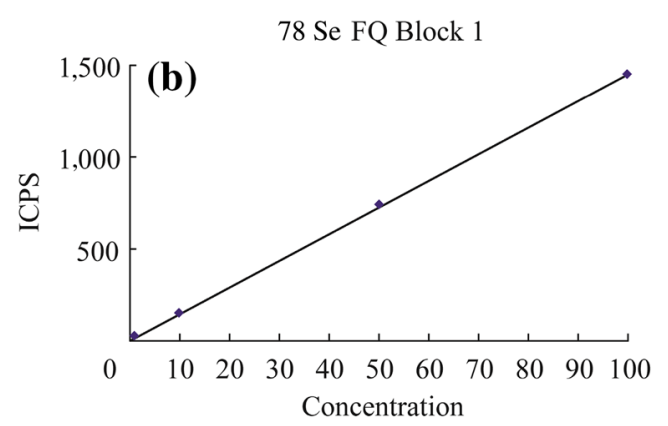

Intercept CPS $=2.869575$ Intercept Conc $=0.196642$ Sensitivity $=14.594932$ Correlation Coeff $=0.999922$

Fig. 2 Calibration curves of arsenic and selenium conducted by ICP/ MS

Table 4 summarizes the results of the thickness, the ash yield, and the observed content of arsenic, selenium and Ge in the studied samples from the Wulantuga ore deposit, as well as their comparisons with average values for Chinese and world low-rank coals.

Compared to the coals (the content of Ge is as high as $274 \mu \mathrm{g} / \mathrm{g}$ ) from the Wulantuga Ge ore deposit, the present Ge-poor coal samples display lower Ge content (with a weighted average concentration of $3.42 \mu \mathrm{g} / \mathrm{g}$ ). It is a lowash coal, according to Chinese Standard GB/T 15224.12010 (2010); coals with ash yield between $10.01 \%$ and $20 \%$ are low-ash coals. The average ash yield (10.59\%) presented in Ge-poor coals is higher than that in high-Ge coals $(8.77 \%)$ reported by Dai et al. (2012a).

\subsection{Arsenic}

Arsenic is one of the most environmentally-sensitive elements in coal and is easily released into the atmosphere in the form of gas during coal combustion. A number of cases concerning the damage and carcinogenicity of arsenic on human health have been reported not only in China but in several other countries (Vladimir and Karel 1977; Vladimir et al. 1977; Finkelman 1999; Zheng et al. 1999). Hence, the abundance and occurrence modes of arsenic in coal have previously been described in a greater detail. 
Table 1 Calibration curves and method detection limit (MDL) of arsenic and selenium

\begin{tabular}{lllllc}
\hline Elements & Isotopes & Linearity $(\mu \mathrm{g} / \mathrm{L})$ & Determination coefficient & MDL $(\mu \mathrm{g} / \mathrm{L})$ & RSD $(\%)$ \\
\hline Arsenic & 75 & $1-100$ & 0.999947 & 0.057 & 0.603 \\
Selenium & 78 & $1-100$ & 0.999922 & 0.216 & 4.282 \\
\hline
\end{tabular}

Table 2 Defined and measured contents of arsenic and selenium $(\mu \mathrm{g} / \mathrm{L})$ in standard solutions conducted by ICP/MS, $\%$ error $=($ measured defined) $\times 100 /$ defined

\begin{tabular}{|c|c|c|c|c|c|}
\hline Sample & Defined & Measured & Mean CPS & Error & $\%$ Error \\
\hline \multicolumn{6}{|c|}{ (a) Defined and measured contents of arsenic } \\
\hline Blank & 0 & 0 & 111 & 0 & 0.00 \\
\hline CCS4-1PPB & 1.000 & 1.070 & 254 & 0.070 & 7.04 \\
\hline CCS4-10PPB & 10.000 & 10.461 & 1,509 & 0.461 & 4.61 \\
\hline CCS4-50PPB & 50.000 & 50.792 & 6,900 & 0.792 & 1.58 \\
\hline CCS4-100PPB & 100.000 & 99.557 & 13,419 & -0.443 & -0.44 \\
\hline \multicolumn{6}{|c|}{ (b) Defined and measured contents of selenium } \\
\hline Blank & 0 & 0 & 3 & 0 & 0 \\
\hline CCS4-1PPB & 1.000 & 1.083 & 19 & 0.083 & 8.33 \\
\hline CCS4-10PPB & 10.000 & 10.391 & 155 & 0.391 & 3.91 \\
\hline CCS4-50PPB & 50.000 & 50.995 & 747 & 0.995 & 1.99 \\
\hline CCS4-100PPB & 100.000 & 99.462 & 1,455 & -0.538 & -0.54 \\
\hline
\end{tabular}

Table 3 Observed (Obs) and Certified (Cer) values of arsenic and selenium $(\mu \mathrm{g} / \mathrm{g})$ in NIST standard reference coal, as well as relative errors $(\mathrm{RE}, \%)$ and internal solution recovery $(\mathrm{Rec}, \%)$ of the ICPCCT-MS analysis RE $(\%)=\mid \mathrm{Obs}-\mathrm{Cer} 100 \mathrm{I} / \mathrm{Cer}$

\begin{tabular}{|c|c|c|c|c|}
\hline \multirow[t]{2}{*}{ Element } & \multicolumn{4}{|c|}{ NIST $2685 b$} \\
\hline & Cer & Obs & $\mathrm{RE}$ & Rec \\
\hline Arsenic & 12 & 11.24 & 6.33 & 97.59 \\
\hline Selenium & 1.9 & 1.89 & 0.53 & 97.59 \\
\hline
\end{tabular}

The average arsenic concentrations of common Chinese and world low-rank coals are reported to be 3.79 (Dai et al. 2012b) and $7.6 \mu \mathrm{g} / \mathrm{g}$ (Ketris and Yudovich 2009), respectively.

The concentration of As in Ge-poor coals varies from 3.15 to $21.55 \mu \mathrm{g} / \mathrm{g}$, with a weighted average content of $9.14 \mu \mathrm{g} / \mathrm{g}$, much lower than that in the Ge-rich coals $(499 \mu \mathrm{g} / \mathrm{g})$ in the Wulantuga Ge ore deposit as reported by Dai et al. (2012a). However, as indicated in Table 4, the concentrations of arsenic in the six coal ply samples are higher than the average values for Chinese and world lowrank coals, except for sample WLTG-6 (slightly lower than the average value for Chinese coals) and WLTG-1 (slightly lower than the average value for world low-rank coals). Arsenic is enriched in the roof of the No. 6 coal seam $(21.55 \mu \mathrm{g} / \mathrm{g})$, relative to that in the middle and bottom
Table 4 The thickness, ash yield, As, Se, and Ge in the coal benches of the No. 6 coal from Wulantuga ore deposit, Inner Mongolia (elements in $\mu \mathrm{g} / \mathrm{g}$; thickness in $\mathrm{cm}$; ash in \%)

\begin{tabular}{llrlll}
\hline Sample & Thickness & Ash & As & Se & Ge \\
\hline WLTG-0-R & $>50$ & & 21.55 & 0.21 & 1.31 \\
WLTG-1 & 50 & 18.84 & 6.16 & 1.39 & 14.24 \\
WLTG-2 & 50 & 9.65 & 8.94 & 0.20 & 4.23 \\
WLTG-3 & 66 & 9.96 & 12.12 & bdl & 0.07 \\
WLTG-4 & 50 & 7.45 & 12.48 & 0.05 & 0.04 \\
WLTG-5 & 50 & 5.88 & 11.05 & 0.09 & bdl \\
WLTG-6 & 50 & 11.98 & 3.15 & 0.16 & 3.02 \\
WLTG-7-FU1 & & 51.23 & 16.88 & 0.44 & 0.13 \\
WLTG-8-FU2 & & 7.57 & 815 & 0.76 & 168 \\
WLTG-9-FA & & & 17,776 & 14.39 & 8,582 \\
WLTG-10-SL & & & 207 & 0.80 & 596 \\
WLTG-11-PY & & & 2,472 & 0.26 & 17.66 \\
Av. Coal & $316^{*}$ & 10.59 & 9.14 & 0.30 & 3.42 \\
China $^{a}$ & & & 3.79 & 2.47 & 2.78 \\
World $^{b}$ & & & 7.6 & 1 & 2
\end{tabular}

$b d l$ below detection limit, $A v$ weighted average (weighted by thickness of sample interval)

a Average contents of elements in the common Chinese coals (Dai et al. 2012b)

b Average concentration of elements in the world low-rank coals (Ketris and Yudovich 2009); Ash on a dry basis

* Total thickness of coal benches 
portions of the seam section. The contents of arsenic in the fly ash and slag samples derived from high-Ge rich coals are as high as $1.7 \%$ and $207 \mu \mathrm{g} / \mathrm{g}$, respectively. The average content of arsenic in the two fusain samples is $415 \mu \mathrm{g} / \mathrm{g}, 109$ and 55 times higher than that in Chinese and world low-rank coals, respectively.

Previous studies showed that arsenic in coal generally occur in the sulfide, especially in the pyrite with the replacement of sulfur in the lattice (Finkelman 1999; Huggins and Haffman 1996; Chen et al. 2002), these including orpiment $\left(\mathrm{As}_{2} \mathrm{~S}_{3}\right)$, realgar (AsS) and arsenopyrite (FeAsS) (Kolker et al. 2000; Ding et al. 2001). Arsenic is also associated with the oxidation minerals composed of $\mathrm{Fe}$ and arsenic, e.g., scorodite (Chen et al. 2002), getchellite (Dai et al. 2006), clay minerals (Swaine 1990), and phosphate minerals. Additionally, organic-association of arsenic in coal has also been reported (Huggins et al. 1993; Huggins and Haffman 1996; Zhao et al. 1998, 1999). Similar to the Ge-rich coals from the Wulantuga ore deposit previously described by Dai et al. (2012a), the low correlation coefficient of As-ash $(-0.20)$, as well as the high contents of arsenic in the two fusain samples, indicates that a large proportion of arsenic in the Wulantuga samples is associated with organic matters. Whereas the high content of arsenic in the WLTG-11-PY sample $(2,472 \mu \mathrm{g} / \mathrm{g})$ suggests that arsenic also occurs in pyrite, in accordance with previous investigations (Dai et al. 2012a). The arsenic in the fly ash sample probably distributes in the secondary (Gebearing complex oxides) and primary (sulfides) minerals (Dai et al. 2014).

The enrichment of arsenic in the coals has generally been attributed to two genetic types: (1) terrigenous sediment region; (2) epigenetic mineralization, such as arsenicrich hydrothermal fluids and sea water (Chen et al. 2002). The origin of the arsenic from the high-Ge coals is mostly related to the hydrothermal fluids (Dai et al. 2012a); however, arsenic in the Wulantuga Ge-poor coals is associated with sedimentary source region, and to a lesser extent, with hydrothermal fluids.

\subsection{Selenium}

The high concentration of selenium in some Chinese coals (especially "stone coal") had caused a great deal of diseases (Nriagu and Pacyna 1988; Su et al. 1990; Tan and Huang 1991). The improper use of "stone coal" containing high selenium had triggered serious endemic diseases in Hubei province, South China (Chen et al. 2002).

The weighted average content of selenium in seven bench samples from Wulantuga is $0.30 \mu \mathrm{g} / \mathrm{g}$, much lower than that in Chinese $(2.47 \mu \mathrm{g} / \mathrm{g})$ and world low-rank coals $(1 \mu \mathrm{g} / \mathrm{g})$ (Dai et al. 2012b; Ketris and Yudovich 2009), but similar to that in Ge-rich coals $(0.49 \mu \mathrm{g} / \mathrm{g})$ in the
Wulantuga Ge ore deposit (Dai et al. 2012a). As a consequence of the high volatility of selenium,the concentration of selenium in the fly ash sample is as high as $14.39 \mu \mathrm{g} / \mathrm{g}$. Both the low content of Se in the slag $(0.80 \mu \mathrm{g} / \mathrm{g})$ and the high content in the fly ash sample show that the mode of occurrence of selenium in coals is partly associated with organic matter. A number of experiments showed that selenium in coals occurs in pyrite in some cases (Minkin et al. 1984; White et al. 1989; Palmer and Lyons 1996), which can be evidenced by the high correlation coefficient (0.91) between the Se contents and the ash yields in the study areas. However, the concentration of Se in WLTG$11-\mathrm{PY}(0.26 \mu \mathrm{g} / \mathrm{g})$ sample is lower than that in Chinese $(2.47 \mu \mathrm{g} / \mathrm{g}$; Dai et al. 2012b) and world low-rank coals $(1 \mu \mathrm{g} / \mathrm{g}$; Ketris and Yudovich 2009). Furthermore, selenium has also been reported to occur in clay minerals, ferroselite, clausthalite (Finkelman 1999), marcasite (White et al. 1989), galena (Chen et al. 2002) and selenium galena (Dai et al. 2006).

The factors affecting abundance of selenium in coals include coal-forming plants, environments, epigenetic hydrothermal activities, underground water, and coalification advancement. Selenium in coal may adhere to the surface of fine-grained fly ash or in gas and aerosol states during coal combustion, and then was emitted to the atmosphere directly, causing series adverse effects on environments. Besides, the leaching effects of selenium from fly ash are a great concern to soil and underground water (Zhang et al. 2007). All information above suggests that Se in coal needs a great attention for environment concern.

\section{Conclusions}

(1) The comparison of content of arsenic and selenium of observed values in the present study and the certified values of NIST standard reference samples further demonstrates the digestion method using closed-vessel digestion plus collision/reaction cell technology (CCT) of inductively coupled plasma mass spectrometry (ICP/MS) for content determination of arsenic and selenium in coal and coal combustion products were effective and reliable methods.

(2) The Wulantuga Ge-poor coal is characterized by its low-ash yield. The weighted average content of $\mathrm{Ge}$ in the present study is $3.42 \mu \mathrm{g} / \mathrm{g}$, much lower than that in the Ge-rich coals $(273 \mu \mathrm{g} / \mathrm{g})$ in the Wulantuga ore deposit previously reported by Dai et al. (2012a).

(3) The arsenic content in the samples of the present study varies from 3.15 to $21.55 \mu \mathrm{g} / \mathrm{g}$, with a weighted average content of $9.14 \mu \mathrm{g} / \mathrm{g}$, lower than that in the Ge-rich coals $(499 \mu \mathrm{g} / \mathrm{g})$ in the Wulantuga 
ore deposit. Similar to the Ge-rich samples of the No. 6 coal seam in the Wulantuga ore deposit, arsenic in the Ge-poor coals is not only organically associated but also occurs in pyrite. Arsenic in the Wulantuga Ge-poor coals was derived from sedimentary source region, and to a lesser extent, from hydrothermal fluids, in contrary to that in the Ge-rich coals.

(4) The content of selenium in the Ge-poor coals is as low as that in the Ge-rich coals from the Wulantuga ore deposit. Selenium is partly connected with organic matters in the Wulantuga ore deposit.

Acknowledgments The authors are grateful to the anonymous reviewers for their careful comments, which improved the manuscript quality greatly.

Open Access This article is distributed under the terms of the Creative Commons Attribution License which permits any use, distribution, and reproduction in any medium, provided the original author(s) and the source are credited.

\section{References}

Chen P, Huang WH, Tang XY (2002) Features of As content, occurrence in coal and its effect on environment in China. Goal Geol Explor 30(3):1-4 (in Chinese with English abstract)

Chinese Standard GB/T 15224.1-2010 (2010) Classification for quality of coal. Part 1: Ash (in Chinese)

Chinese Standard Method GB/T 482-2008 (2008) Sampling of coal seams (in Chinese)

Dai SF, Ren DY, Hou XQ, Shao LY (2003) Geochemical and mineralogical anomalies of the Late Permian coal in the Zhijin coalfield of southwest China and their volcanic origin. Int J Coal Geol 55:117-138

Dai SF, Ren DY, Tang YG, Yue M, Hao LM (2005) Concentration and distribution of elements in Late Permian coal from western Guizhou Province, China. Int J Coal Geol 61:119-137

Dai SF, Zeng RS, Sun YZ (2006) Enrichment of arsenic, mercury, and thallium in a Late Permian anthracite from Xingren, Guizhou, Southwest China. Int J Coal Geol 66:217-226

Dai SF, Wang XB, Zhou YP, Hower JC, Li DH, Chen WM, Zhu XW, Zou JH (2011) Chemical and mineralogical compositions of silicic, mafic, and alkali tonsteins in the late Permian coals from the Songzao Coalfield, Chongqing, Southwest China. Chem Geol 282:29-44

Dai SF, Wang XB, Seredin VV, Hower JC, Ward CR, O'Keefe JMK, Huang WH, Li T, Li X, Liu HD, Xue WF, Zhao L (2012a) Petrology, mineralogy, and geochemistry of the Ge-rich coal from the Wulantuga Ge ore deposit, Inner Mongolia, China: new data and genetic implications. Int J Coal Geol 90-91:72-99

Dai SF, Ren DY, Chou CL, Finkelman RB, Seredin VV, Zhou Y (2012b) Geochemistry of trace elements in Chinese coals: a review of abundances, genetic types, impacts on human health, and industrial utilization. Int J Coal Geol 94:3-21

Dai SF, Seredin VV, Ward CR, Jiang JH, Hower JC, Song XL, Jiang YF, Wang XB, Gornostaeva T, Li X, Liu HD, Zhao L, Zhao CL (2014) Composition and modes of occurrence of minerals and elements in coal combustion products derived from high-Ge coals. Int J Coal Geol 121:79-97
Ding ZH, Zheng BS, Long JP, Belkin HE, Finkelman RB, Chen CG, Zhou DX, Zhou YS (2001) Geological and geochemical characteristics of high arsenic coals from endemic arsenosis areas in southwestern Guizhou Province, China. Appl Geochem $16: 1353-1360$

Finkelman RB (1999) Trace elements in coal: environmental and health significance. Biol Trace Elem Res 67:2-9

Huang WH, Sun L, Ma YY, Wan H, Tang XY, Du G, Wu W, Qin SL, Finkelman RB (2007) Distribution and geological feature of the Coal-Ge deposit of Shengli coalfield in Inner Mongolia of China. J China Coal Soc 32(11):1147-1151 (in Chinese with English abstract)

Huggins FE, Haffman GP (1996) Modes of occurrence of trace elements in coal from XAFS spectroscopy. Int $\mathrm{J}$ Coal Geol 32:31-53

Huggins FE, Shah N, Zhao J (1993) Nondestructive determination of trace elements speciation in coal and coal ash by XAFS spectroscopy. Energy Fuels 7:482-489

Ketris MP, Yudovich YE (2009) Estimations of Clarkes for carbonaceous biolithes: world average for trace element contents in black shales and coals. Int J Coal Geol 78:135-148

Kolker A, Huggins FE, Palmer CA (2000) Mode of occurrence of arsenic in four US coals. Fuel Process Technol 63:167-168

Li X, Dai SF, Zhang WG, Li T, Zheng X, Chen WM (2014) Determination of As and Se in coal combustion products using closed vessel microwave digestion and collision/reaction cell technology (CCT) of inductively coupled plasma mass spectrometry (ICP-MS). Int J Coal Geol 124:1-4

Minkin JA, Finkelman RB, Thompson CL (1984) Micro characterization of arsenic and selenium-bearing pyrite in Upper Freeport coal, Indiana County. PA Scan Electron Microsc 4:1515-1524

Nriagu JO, Pacyna JM (1988) Quantitative assessment of world-wide contamination of air, water and soil by trace elements. Nature 333(6169):134-139

Palmer CA, Lyons PC (1996) Selected elements in major minerals from bituminous coal as determined by INAA: implications for removing environmentally sensitive elements from coal. Int J Coal Geol 32:151-166

Ren DY, Zhao FH, Wang YQ (1999) Distribution of minor and trace elements in Chinese coals. Int J Coal Geol 40:109-118

Sha JG (2007) Cretaceous stratigraphy of northeast China: nonmarine and marine correlation. Cretac Res 28:146-170

Shao LY, Lu J, Tim J, Rod G, Shang LJ, Shen ZJ, Zhang PF (2006) Mineralogy and geochemistry of the high-organic sulfur coals from the carbonate coal measures of the Late Permian in central Guangxi. J China Coal Soc 31(6):770-775 (in Chinese with English abstract)

Su HC, Yan LR, Rao SQ, Jian XH, Mao DJ (1990) Investigation of the cause of the origination of the environmental selenium area in the Exi autonomous prefecture of Hubei province. Environ Sci 11(2):86-89 (in Chinese)

Swaine DJ (1990) Trace elements in coal. Botterworths, London, $178-386$

Tan JA, Huang YJ (1991) Selenium in geo ecosystem and its relation to endemic diseases in China. Water Air Soil Pollut 57-58:59-68

Tang XY, Huang WH (2004) Trace element in Chinese Coals. Beijing Commerce and Trade Press, Beijing, 54-280 (in Chinese with English abstract)

Vladimir B, Karel S (1977) Health aspects of burning coal with a high arsenic content. Environ Res 13:378-385

Vladimir B, Karel S, Vladimir C, Jaroslav P (1977) Health aspects of burning coal with a high arsenic content. Environ Res 13:386-395

White RN, Smith JV, Spears DA (1989) Analysis of iron sulphides from UK coal by synchrotron radiation X-ray fluorescence. Fuel 68:1480-1486 
Zhang Y, Liu GJ, Zheng LG, Chou CL, Qi CC (2007) Environmental geochemistry of selenium in Chinese coal. Bull Mineral, Petrol Geochem 26(4):389-398 (in Chinese with English abstract)

Zhao FH, Ren DY, Zheng BS (1998) Modes of occurrence of arsenic in high arsenic coals from EXAFS spectroscopy. Sci Bull 43(14):21-23 (in Chinese with English abstract)
Zhao FH, Ren DY, Yin SJ (1999) The study of the occurrence of arsenic in coal by sequential chemical extract. Environ Sci 20(3):79-81 (in Chinese with English abstract)

Zheng BS, Ding ZH, Huang RG, Zhu JM, Yu XY, Wang AM, Zhou DX, Mao DJ, Su HC (1999) Issues of health and disease relating to coal use in southwestern China. Int J Coal Geol 40:119-132 